\title{
Investigation of the Effects of Inulin and $\beta$-Glucan on the Physical and Sensory Properties of Low-Fat Beef Burgers Containing Vegetable Oils: Optimisation of the Formulation Using D-Optimal Mixture Design
}

\author{
Roya Afshari ${ }^{1}$, Hedayat Hosseini ${ }^{1 *}$, Ramin Khaksar ${ }^{1}$, Mohammad Amin Mohammadifar ${ }^{1}$, \\ Zohre Amiri ${ }^{1}$, Rozita Komeili ${ }^{1}$ and Amin Mousavi Khaneghah ${ }^{2}$ \\ ${ }^{1}$ National Nutrition and Food Technology Research Institute, Faculty of Nutrition Sciences and Food \\ Technology, Shahid Beheshti University of Medical Sciences, 1981619573 Tehran, Iran \\ ${ }^{2}$ Department of Food Science, Faculty of Food Engineering, University of Campinas (UNICAMP), \\ 13083-862 Campinas, São Paulo, Brazil \\ Received: November 9, 2014 \\ Accepted: July 15, 2015
}

\begin{abstract}
Summary
In this study, the D-optimal mixture design methodology was applied to determine the optimised proportions of inulin, $\beta$-glucan and breadcrumbs in formulation of low-fat beef burgers containing pre-emulsified canola and olive oil blend. Also, the effect of each of the ingredients individually as well as their interactions on cooking characteristics, texture, colour and sensory properties of low-fat beef burgers were investigated. The results of this study revealed that the increase of inulin content in the formulations of burgers led to lower cooking yield, moisture retention and increased lightness, overall acceptability, mouldability and desired textural parameters. In contrast, incorporation of $\beta$-glucan increased the cooking yield, moisture retention and decreased lightness, overall acceptability, mouldability and desired textural parameters of burger patties. The interaction between inulin and $\beta$-glucan improved the cooking characteristics of the burgers without significantly negative effect on the colour or sensory properties. The results of the study clearly stated that the optimum mixture for the burger formulation consisted of (in $\mathrm{g}$ per $100 \mathrm{~g}$ ): inulin 3.1, $\beta$-glucan 2.2 and breadcrumbs 2.7. The texture parameters and cooking characteristics were improved by using the mixture of inulin, $\beta$-glucan and breadcrumbs, without any negative effects on the sensory properties of the burgers.
\end{abstract}

Key words: D-optimal mixture design, inulin, $\beta$-glucan, low-fat beef burgers, canola and olive oil blend

\section{Introduction}

In recent years, excessive consumption of meat products has been associated with obesity, hypertension, ischaemic heart disease, even different forms of cancer due to high amounts of saturated fatty acids (SFAs), cholesterol and sodium $(1,2)$. Since meat and meat products still play an important role in providing many essential nutrients for optimal growth, improving the quality of currently available products in order to develop new healthy meat products is essential.

In order to enhance the quality of meat products, a lot of research has been conducted recently to reduce the amount of animal fat and/or replace it with unsaturated 
fatty acids in formulations for a variety of products (3-6). Since vegetable oils contain higher levels of unsaturated fatty acids and are free from cholesterol when compared to animal fats, their incorporation into meat formulations could improve nutritional benefits of the final product (5). Reduction of animal fat is a big challenge for the meat industry because it causes negative alterations in the textural and sensory properties of the meat products $(3,5,7)$. Numerous studies investigated possible addition of dietary fibre, which could improve the textural and sensory properties but also enhance the nutritional properties. Therefore, inclusion of dietary fibre is one of the main possible solutions currently investigated in food industry $(3,8)$.

$\beta$-Glucan, which is known as a prebiotic, is a soluble dietary fibre that originates from oat kernel (9). It is applied as a fat substitute in beef patties (10) and sausages (8). Inulin is another soluble dietary fibre obtained mainly from chicory root and it is also known as a food prebiotic ingredient (11), applied in a variety of meat products $(12,13)$.

Burgers and patties are common meat products, widely consumed in different societies. Therefore, introduction of some changes in formulations in order to improve their health-related properties is of particular interest in the meat industry.

Mixture design methodology is a new approach that can be used to determine the functions of the ingredients in processed foods and provide valuable information about ingredient interactions by applying reduced numbers of experimental trials (14). As far as we know, the effects of incorporation of the combination of inulin and $\beta$-glucan on the physical and sensory properties of low-fat burgers containing vegetable oil have not been investigated previously. Hence, the objective of this research is to apply the D-optimal mixture design to determine the influence of the addition of inulin, $\beta$-glucan and breadcrumbs. Also, the effect of mixture interactions on the properties of low-fat beef burgers containing pre-emulsified canola and olive oil blend was investigated in order to obtain the optimal mixture proportions to formulate healthy low-fat beef burgers.

\section{Materials and Methods}

\section{Materials}

Sixteen boneless cuts from heifer carcasses (brisket and flank) of mean age 17-24 months were obtained from Gooshtiran Co. (Tehran, Iran) at $48 \mathrm{~h}$ post mortem and stored in refrigerators $\left(4^{\circ} \mathrm{C}\right)$. All visible fat and connective tissue were removed. Proximate composition (in $\mathrm{g}$ per $100 \mathrm{~g}$ : moisture 71 , protein 23 , fat 5.5 and ash 0.9 ) of four portions of lean meat were analysed prior to burger manufacture.

Inulin Frutafit TEX ${ }^{\circledR}$ (Roosendaal, The Netherlands) and $\beta$-glucan with $34 \%$ purity (Biovelop International AB, Kimstad, Sweden) were obtained from local suppliers in Iran. Soya protein isolate with a protein content of $94 \%$ was obtained from Shandong Wonderful Industrial Group Co., Ltd. (Dongying, Shandong, PR China). Refined olive oil (16\% SFA, $68 \%$ MUFA and $13 \%$ PUFA) and canola oil (7\% SFA, $64 \%$ MUFA and $24 \%$ PUFA) were purchased from the local factory (Etka Co, Tehran,
Iran). The other ingredients including sodium chloride, black pepper and breadcrumbs were purchased from local producers.

\section{Methods}

\section{Preparation of canola and olive oil blend}

The oil-in-water emulsion (in g per 100 g: olive oil 2.4, canola oil 3.6, soya protein isolate 0.6 and water 4.8 ) was prepared with procedure described by Bloukas et al. (15).

\section{Beef burger preparation}

The formulation of low-fat beef burgers consisted of $48.5 \%$ lean meat. It was minced using a grinder (model WWB 200; Laska, Traun, Austria) and the ingredients (in $\%: \mathrm{NaCl} 1.2$, black pepper 0.2 , powdered cinnamon 0.05 and chopped onion 30) were added to the minced lean meat, then mixed for $5 \mathrm{~min}$ in a commercial mixer (model R6-02VB; Robot Coupe, Vincennes, France).

Then, the pre-emulsified canola and olive oil blend $(11.4 \%)$ and selected mass fractions of powdered inulin, powdered $\beta$-glucan and breadcrumbs were added to the mixture (Table 1). The mixture of ingredients was homogenized in the commercial mixer for $8 \mathrm{~min}$ to form burger paste. It was reground through the $6-\mathrm{mm}$ plate, and then portions of $100 \mathrm{~g}$ of the burger mix were machine-shaped into a round mould (diameter $10 \mathrm{~cm}$ and height $1 \mathrm{~cm}$ ). Beef burgers were then placed on stainless steel trays, wrapped with polyvinyl chloride plastic, and stored in boxes in commercial freezers $\left(-18^{\circ} \mathrm{C}\right)$ until the day of analysis.

Table 1. D-optimal mixture design used to study the effects of the addition of breadcrumbs, inulin and $\beta$-glucan (at total mass fraction of $8 \mathrm{~g}$ per $100 \mathrm{~g}$ of burgers in each formulation) on cooking characteristics, texture, colour and sensory properties of low-fat beef burgers

\begin{tabular}{cccc}
\hline Formulation & $w$ (breadcrumb) $/ \%$ & $w$ (inulin) $/ \%$ & $w(\beta$-glucan $) / \%$ \\
\hline 1 & 0.0 & 8.0 & 0.0 \\
2 & 1.3 & 1.3 & 5.3 \\
3 & 0.0 & 5.3 & 2.7 \\
4 & 0.0 & 4.0 & 4.0 \\
5 & 5.3 & 1.3 & 1.3 \\
6 & 8.0 & 0.0 & 0.0 \\
7 & 0.0 & 0.0 & 8.0 \\
8 & 2.7 & 2.7 & 2.7 \\
9 & 4.0 & 4.0 & 0.0 \\
10 & 0.0 & 2.7 & 5.3 \\
11 & 4.0 & 0.0 & 4.0 \\
12 & 2.7 & 2.7 & 2.7 \\
13 & 4.0 & 4.0 & 0.0 \\
14 & 2.7 & 0.0 & 5.3 \\
\hline
\end{tabular}

\section{Cooking procedure and cooking characteristics}

Beef burgers were thawed at $5{ }^{\circ} \mathrm{C}$ for $12 \mathrm{~h}$. The samples were cooked according to the American Meat Science Association methodology (16). A cooker (CFS FlowCook 600/6000; GEA, Bakel, The Netherlands) was used to heat the burgers to obtain an internal temperature of $71^{\circ} \mathrm{C}$. 
The cooking yield $(\eta)$ of burgers was determined by measuring the mass of three patties for each formula before and after cooking using the following equation:

$$
\eta_{\text {cooking }}=\left(m_{\text {cooked burger }} / m_{\text {raw burger }}\right) \cdot 100
$$

The diameter $(d)$ of three burgers of each formulation was measured at ambient temperature $\left((25 \pm 1){ }^{\circ} \mathrm{C}\right)$ before and after cooking. The following equation was used to calculate the diameter reduction:

$$
d_{\text {reduction }}=\left(\left(d_{\text {raw burger }}-d_{\text {cooked burger }}\right) / d_{\text {raw burger }}\right) \cdot 100
$$

To measure the amount of moisture and fat retained in each burger, the following equations were used:

$$
\begin{gathered}
\text { Moisture retention }=\left(\left(m_{\text {cooked burger }} \cdot m_{\text {moisture in cooked burger }}\right) /\right. \\
\left.\qquad /\left(m_{\text {raw burger }} \cdot m_{\text {moisture in raw burger }}\right)\right) \cdot 100 \\
\text { Fat retention }=\left(\left(m_{\text {cooked burger }} \cdot m_{\text {fat in cooked burger }}\right) /\right. \\
\quad\left(m_{\text {raw burger }} \cdot m_{\text {fat in raw burger }}\right) \cdot 100
\end{gathered}
$$

Texture profile analysis

The texture properties of cooked beef burgers were evaluated using a texture analyser (M 350-10 CT; Testometric Co. Ltd., Rochdale, Lancashire, UK). Prior to analysis, beef burgers were thawed for $12 \mathrm{~h}$ at $5{ }^{\circ} \mathrm{C}$. Texture profile analysis test was performed using one portion of each beef burger (height $1 \mathrm{~cm}$ and diameter $2 \mathrm{~cm}$ ) which was compressed to $50 \%$ of its original height with a cylindrical probe of $3.6 \mathrm{~cm}$ in diameter and a cross-head speed of $2 \mathrm{~mm} / \mathrm{s}$. Force-deformation curves were applied to determine the textural measurements including hardness, cohesiveness and gumminess. Measurements were performed at ambient temperature $\left((25 \pm 1)^{\circ} \mathrm{C}\right)$.

\section{Colour determination}

Beef burgers were thawed for $12 \mathrm{~h}$ at $5{ }^{\circ} \mathrm{C}$ prior to colour determination. The colour values of burgers were determined with CIELab space values ( $L^{*}=$ relative lightness, $a^{*}=$ relative redness and $b^{*}=$ relative yellowness) using a Chromo meter (CR-400; Konica Minolta Sensing, Inc., Osaka, Japan). Colourimeter was calibrated with the standard tile $\left(L^{*}=97.83, a^{*}=-0.43, b^{*}=+1.98\right)$. Colour properties were measured on three different locations in each of the three examined samples. The calculated results were expressed with mean value of these measurements.

\section{Sensory evaluation}

Sensory analysis was done using a hedonic test as described by Mann and Whitney (17). Low-fat beef burgers used for sensory evaluation were cooked on a cooker (mentioned above), cut into four equally sized wedges, and one piece of each sample was placed on a white paper plate. Thirty untrained assessors were chosen among the students and staff of Food Science and Technology Department, Shahid Beheshti University of Medical Sciences, Tehran, Iran. The assessors were asked to sit in private booths with fluorescent lighting at $25{ }^{\circ} \mathrm{C}$ and evaluate the overall acceptability of samples. Hedonic scores ranging from 1 to 9 , representing a scale from extreme dislike to extreme like, respectively, were used for sensory evaluation. Mineral water and unsalted soda crackers were provided to cleanse the palate between the samples.
In order to evaluate the mouldability of burger patties, ten expert operators from one of the meat producing companies (Gooshtiran Co., Tehran, Iran) were invited to give their scores. A 5-point hedonic scale was used to evaluate this attribute, with 1 being the least mouldable and 5 being the most mouldable.

\section{Experimental design and optimisation}

D-optimal mixture design was used to investigate the effects of incorporation of inulin, $\beta$-glucan and breadcrumbs on cooking characteristics, textural, colour and sensory properties of low-fat beef burgers containing vegetable oils to determine the optimum mixture proportions in the formulation. Design-Expert ${ }^{\circledR}$ software v. 7.1.5 (Stat-Ease Inc., Minneapolis, MN, USA) was applied to analyse the data and model the responses. Combined effects of breadcrumb $\left(X_{1}\right)$, inulin $\left(X_{2}\right)$, and $\beta$-glucan $\left(X_{3}\right)$ content were evaluated using a six-level three-factor design. The mass fractions of these three ingredients varied from 0 to $8 \mathrm{~g}$ per $100 \mathrm{~g}$ of each burger. A total number of $14 \mathrm{ex}$ periments including 12 different combinations of breadcrumbs, inulin and $\beta$-glucan content in two repetitions were performed according to the experimental design (Table 1). Numerical optimisation techniques of Design-Expert software were used for the simultaneous optimisation of four responses including cooking yield, reduction in diameter, overall acceptability and mouldability of the burgers. Desired criteria for each variable and selected four responses were chosen. All the variables were kept in the range, while the responses were either maximised or minimised. Numerical optimisation was used to find the best solution, with high desirability of the final product.

\section{Statistical data analysis}

The following three equation models were fitted to each of the responses $(Y)$ with independent variables $(X)$, where $b$ is the regression coefficient calculated from the experimental data by multiple regressions.

$$
\begin{gathered}
\text { Linear model: } Y=b_{1} X_{1}+b_{2} X_{2}+b_{3} X_{3} \\
\text { Quadratic model: } \\
\begin{array}{c}
Y=b_{1} X_{1}+b_{2} X_{2}+b_{3} X_{3}+b_{12} X_{1} X_{2}+b_{13} X_{1} X_{3}+b_{23} X_{2} X_{3} \\
\text { Cubic model: } \\
Y=b_{1} X_{1}+b_{2} X_{2}+b_{3} X_{3}+b_{12} X_{1} X_{2}+b_{13} X_{1} X_{3}+b_{23} X_{2} X_{3}+b_{123} X_{1} X_{2} X_{3}
\end{array}
\end{gathered}
$$

The importance of all parts in the polynomial was evaluated statistically by computing the F-value at $\mathrm{p}=0.05$ or 0.01 .

All parametric tests were performed in triplicate for each experiment and the reported data were expressed as the mean value with standard deviation. The tests were analysed using the SPSS v. 17.0 for Windows (SPSS Inc., Chicago, IL, USA) and statistical significance was calculated by Tukey's multiple range tests where $p<0.05$ or 0.01 was taken as the significance. Sensory evaluation was analysed by the same software according to the methods described by Mann and Whitney (17). Correlation analyses were conducted using the Pearson correlation model where $\mathrm{p}<0.05$ or 0.01 was taken as significant. 


\section{Results and Discussion}

\section{Cooking characteristics of low-fat beef burgers}

The presence of $\beta$-glucan in low-fat beef burger formulations led to higher cooking yield values, whereas increasing the level of powdered inulin up to $8 \%$ decreased the cooking yield (Table 2, formulation 1). As shown in Table 2, the highest cooking yield $(76.1 \%)$ and moisture retention $(66.8 \%)$ values were observed in formulation 11 containing $4 \% \beta$-glucan and $4 \%$ breadcrumbs, while the lowest cooking yield $(50.2 \%)$ and moisture retention (36.2 $\%$ ) values were found in the burgers containing $8 \%$ inulin (Table 2). Significant correlation between cooking yield and moisture retention was observed $(\mathrm{R}=0.99, \mathrm{p}<0.01)$.

As it can be seen in Table 3, only the linear terms and the two-component interaction (between inulin and $\beta$-glu- can) had a highly significant effect on cooking yield and moisture retention $(\mathrm{p}<0.01)$. Apparently, absolute value of breadcrumbs and $\beta$-glucan coefficients was greater than of inulin, which resulted in more significantly positive effect of $\beta$-glucan and breadcrumbs in comparison with inulin on cooking yield and moisture retention. The contour plots of cooking yield and moisture retention show that the highest values of these properties were found in the $\beta$-glucan vertex and the lowest one appeared to be in the inulin vertex (Figs. 1a and $b$ ).

Among the burgers, fat retention was higher in formulations 1 and 3, with 8 and $5.3 \%$ inulin, respectively (Table 2), while it was lower in formulations 6 and 7, which contained only breadcrumbs or $\beta$-glucan, respectively. As shown in Table 3, the linear and non-linear terms had a significant effect on fat retention $(p<0.05)$. Fat

Table 2. Experimental results for cooking characteristics of each burger formulation

\begin{tabular}{ccccc}
\hline Formulation & $\eta_{\text {cooking }} / \%$ & Moisture retention/\% & Fat retention/\% & $d_{\text {reduction }} / \%$ \\
\hline 1 & $(50.2 \pm 0.8)^{\mathrm{a}}$ & $(36.2 \pm 2.6)^{\mathrm{a}}$ & $(100.1 \pm 1.1)^{\mathrm{g}}$ & $(23.9 \pm 0.8)^{\mathrm{f}}$ \\
2 & $(76.1 \pm 0.7)^{\mathrm{e}}$ & $(65.8 \pm 0.5)^{\mathrm{fgh}}$ & $(96.1 \pm 0.9)^{\mathrm{ef}}$ & $(13.8 \pm 0.3)^{\mathrm{bc}}$ \\
3 & $(64.9 \pm 1.1)^{\mathrm{b}}$ & $(53.3 \pm 0.8)^{\mathrm{bc}}$ & $(98.3 \pm 0.3)^{\mathrm{fg}}$ & $(18.9 \pm 0.8)^{\mathrm{e}}$ \\
4 & $(72.7 \pm 0.3)^{\mathrm{d}}$ & $(61.7 \pm 0.1)^{\mathrm{ef}}$ & $(91.5 \pm 0.5)^{\mathrm{d}}$ & $(12.4 \pm 0.5)^{\mathrm{ab}}$ \\
5 & $(72.2 \pm 0.3)^{\mathrm{cd}}$ & $(60.9 \pm 1.2)^{\mathrm{de}}$ & $(95.3 \pm 0.8)^{\mathrm{e}}$ & $(16.7 \pm 0.7)^{\mathrm{de}}$ \\
6 & $(69.7 \pm 0.8)^{\mathrm{c}}$ & $(57.4 \pm 1.1)^{\mathrm{cd}}$ & $(84.2 \pm 0.9)^{\mathrm{b}}$ & $(16.7 \pm 0.2)^{\mathrm{de}}$ \\
7 & $(76.1 \pm 0.6)^{\mathrm{e}}$ & $(66.6 \pm 0.8)^{\mathrm{gh}}$ & $(84.3 \pm 0.6)^{\mathrm{b}}$ & $(10.9 \pm 0.7)^{\mathrm{a}}$ \\
8 & $(73.7 \pm 1.2)^{\mathrm{de}}$ & $(63.8 \pm 0.6)^{\mathrm{efg}}$ & $(88.4 \pm 0.4)^{\mathrm{c}}$ & $(11.6 \pm 0.3)^{\mathrm{ab}}$ \\
10 & $(63.14 \pm 0.13)^{\mathrm{b}}$ & $(50.9 \pm 0.2)^{\mathrm{b}}$ & $(91.7 \pm 0.2)^{\mathrm{d}}$ & $(18.8 \pm 0.4)^{\mathrm{e}}$ \\
11 & $(75.8 \pm 0.3)^{\mathrm{e}}$ & $(66.7 \pm 0.2)^{\mathrm{gh}}$ & $(87.2 \pm 1.2)^{\mathrm{c}}$ & $(12.7 \pm 1.2)^{\mathrm{abc}}$ \\
13 & $(76.1 \pm 0.5)^{\mathrm{f}}$ & $(66.8 \pm 0.2)^{\mathrm{h}}$ & $(94.2 \pm 0.2)^{\mathrm{e}}$ & $(14.8 \pm 0.8)^{\mathrm{cd}}$ \\
14 & $(74.0 \pm 1.1)^{\mathrm{de}}$ & $(63.5 \pm 0.6)^{\mathrm{def}}$ & $(88.7 \pm 0.3)^{\mathrm{fg}}$ & $(11.3 \pm 0.5)^{\mathrm{a}}$ \\
\end{tabular}

Values are presented as mean \pm standard deviation of three repetitions. Mean values in the same column with the same letter are not significantly different

For the composition of formulations see Table 1

Table 3. Regression and correlation coefficients of the adjusted model in the mixture design

\begin{tabular}{|c|c|c|c|c|c|c|c|c|}
\hline \multirow{2}{*}{ Variable } & \multicolumn{3}{|c|}{ Linear terms } & \multicolumn{4}{|c|}{ Non-linear terms } & \multirow{2}{*}{$\mathrm{R}^{2}$} \\
\hline & $\mathrm{b}_{1}$ & $\mathrm{~b}_{2}$ & $\mathrm{~b}_{3}$ & $b_{12}$ & $\mathrm{~b}_{13}$ & $b_{23}$ & $\mathrm{~b}_{123}$ & \\
\hline Cooking yield/\% & $73.9^{* *}$ & $49.7^{* *}$ & $75.77^{* *}$ & 13.0 & 4.0 & $36.16^{* *}$ & 69.06 & 0.98 \\
\hline Moisture retention/\% & $57.9^{* *}$ & $35.5^{* *}$ & $65.82^{* *}$ & 15.7 & 6.3 & $41.33^{* *}$ & 84.95 & 0.96 \\
\hline Fat retention/\% & $84.3^{* *}$ & $101.0^{* *}$ & $83.74^{* *}$ & -5.6 & $38.8^{* *}$ & -1.20 & $\ldots$ & 0.92 \\
\hline Diameter reduction/\% & $16.1^{* *}$ & $21.3^{* *}$ & $9.13^{* *}$ & $\ldots$ & $\ldots$ & $\ldots$ & $\ldots$ & 0.81 \\
\hline Hardness/N & $19.8^{* *}$ & $36.1^{* *}$ & $5.49^{* *}$ & $-30.5^{* *}$ & $-23.4^{* *}$ & $-65.76^{* *}$ & $\ldots$ & 0.98 \\
\hline Cohesiveness & $0.67^{* *}$ & $0.64^{* *}$ & $0.55^{* *}$ & $-0.29^{* *}$ & $-0.15^{* *}$ & $-0.38^{* *}$ & $\ldots$ & 0.94 \\
\hline Gumminess/N & $13.2^{* *}$ & $22.06^{* *}$ & $3.06^{* *}$ & $-24.9^{* *}$ & $-16.9^{* *}$ & $-41.4^{* *}$ & $\ldots$ & 0.99 \\
\hline Lightness & $19.3^{* *}$ & $20.5^{* *}$ & $17.19^{* *}$ & $-3.8^{*}$ & $-3.3^{*}$ & $-3.2^{*}$ & $\ldots$ & 0.92 \\
\hline Redness & $4.1^{* *}$ & $3.8^{* *}$ & $5.94^{* *}$ & $\ldots$ & $\ldots$ & -2.67 & $\ldots$ & 0.86 \\
\hline Yellowness & $36.0^{* *}$ & $11.5^{* *}$ & $15.01^{* *}$ & $-13.0^{* *}$ & 2.5 & $\ldots$ & $\ldots$ & 0.96 \\
\hline Mouldability & $4.47^{* *}$ & $4.77^{* *}$ & $0.69^{* *}$ & $\ldots$ & $\ldots$ & $\ldots$ & $\ldots$ & 0.77 \\
\hline
\end{tabular}

$b_{1}=$ breadcrumbs, $b_{2}=$ inulin, $b_{3}=\beta$-glucan; " significant $(p<0.05)$, "*highly significant $(p<0.01)$ 
retention values were significantly greater in the burgers made with inulin only, in those with the mixture of inulin and breadcrumbs, and those with the mixture of $\beta$-glucan and breadcrumbs than in other burgers (Fig. 1c).

A dimensional change is one of the most important alterations of burgers which can be affected by incorporation of new ingredients. In this research, the greatest reduction in the diameter was observed when $8 \%$ inulin was added while the smallest change was detected when only $\beta$-glucan was added (Table 2 ). The adjusted regression coefficients showed that only the linear terms had a significant effect $(p<0.01)$ on the diameter reduction of beef burgers (Table 3). In this way, coefficient value of inulin was greater than of breadcrumbs and $\beta$-glucan. The higher reduction in diameter values of burgers found in the vertex of inulin was confirmed by contour plot (Fig. 1d).

As it has been mentioned, $\beta$-glucan, followed by breadcrumbs, had greater influence on cooking yield and moisture retention when compared with inulin. Losses of fat and moisture during cooking were minimised by the tight and porous networks of $\beta$-glucan which could entrap fat and water within the meat protein system. Likewise, Piñero et al. (10) demonstrated that $\beta$-glucan was effective in retaining moisture and fat and also increasing the cooking yield in low-fat beef patties because three-dimensional matrices are created within the meat protein system. The effect of the addition of the breadcrumbs on the properties of beef burgers can be attributed to wheat starch. Swelled starch granules embedded in protein gel matrices form heat-induced texture during the cooking, which increased the water-binding properties of protein gel matrices (18). Zeidler et al. (19) found that incorporation of $10 \%$ breadcrumbs into the Salisbury steaks reduced the yield losses to $6.6 \%$ of its initial mass. Under the examined conditions, inulin, even at higher proportions, reduced the moisture retention and cooking yield probably because it does not form tight and porous gel structures in the burger system. Lower moisture retention and cooking yield of the formulation containing inulin could be attributed to hydrolysation of the dissolved long-chain inulin molecules at temperatures above $80^{\circ} \mathrm{C}$ into the smaller chain ones, which are unable to form a gel (20). This finding was in contrast to the results of previous research which found that incorporation of $6 \%$ inulin in powdered form into a meat emulsion system decreased the cooking loss (21). As mentioned previously, inulin and $\beta$-glucan interaction had greater synergistic effect on moisture retention and cooking yield than the effect of interaction of other two components (the mixture of inulin and breadcrumb and/or the mixture of breadcrumbs and $\beta$-glucan). However, this effect was lower when only $\beta$-glucan was applied $(\mathrm{p}<0.05)$ when compared with when inulin and $\beta$-glucan mixture was incorporated in the formulation. A possible explanation is that the inulin chain might disturb the interaction of $\beta$-glucan with meat protein, and as a consequence, cause a significant cooking loss.

All of the added ingredients (inulin, $\beta$-glucan and breadcrumbs) had a significant effect on the changes in
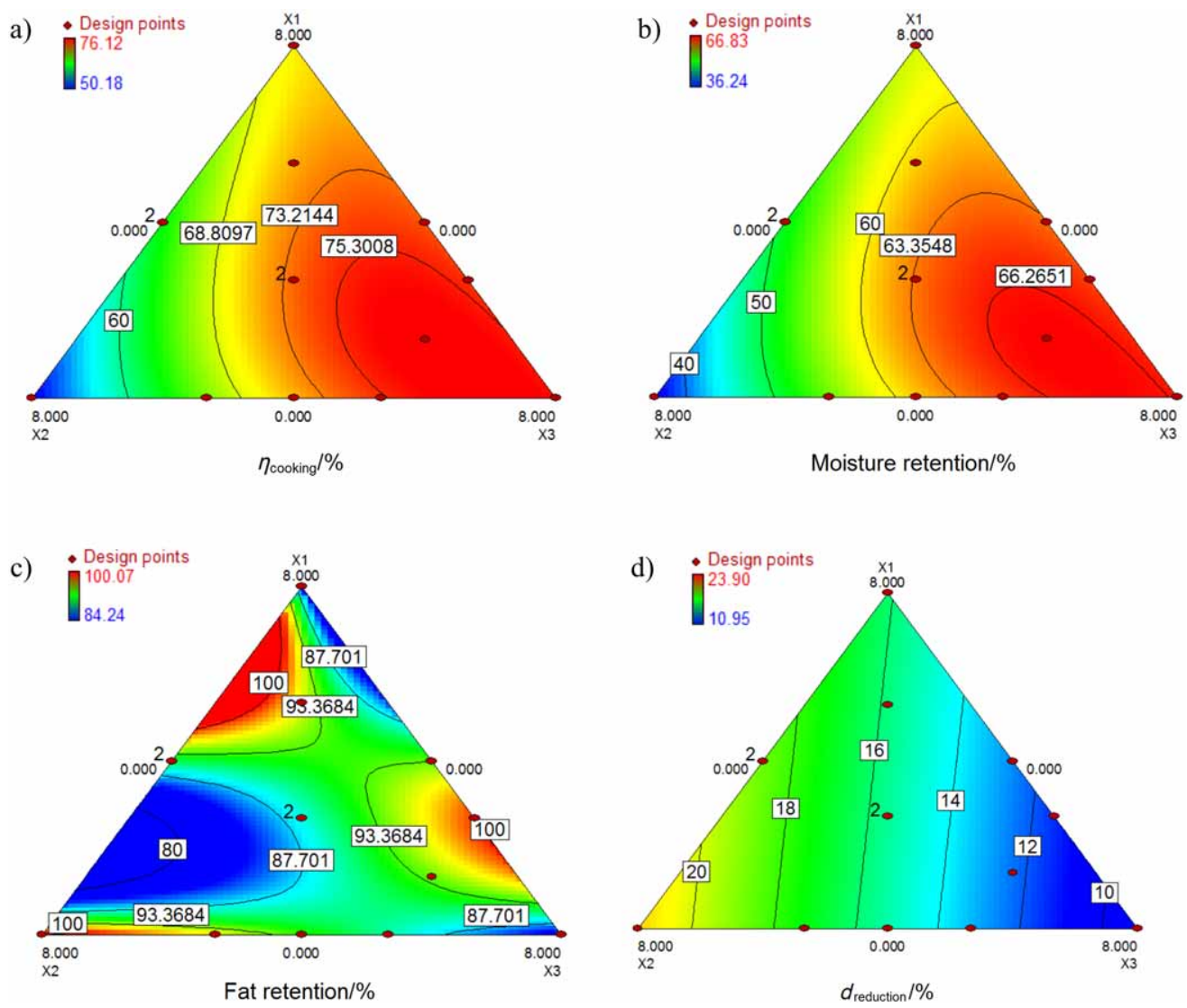

Fig. 1. Contour plots for the effect of the addition of breadcrumbs $\left(X_{1}\right)$, inulin $\left(X_{2}\right)$ and $\beta$-glucan $\left(X_{3}\right)$ on cooking yield, moisture retention, fat retention and reduction in the diameter of the low-fat beef burgers containing canola and olive oil blend 
the diameter of beef burgers $(p<0.05)$. Increasing the mass fraction of inulin in the formulations had the greatest influence on the beef burger diameter, followed by breadcrumbs and $\beta$-glucan. The smallest reduction in the diameter of samples containing $\beta$-glucan during cooking could be due to the stabilising effect of the $\beta$-glucan that holds meat particles connected to each other (10). In this study, a significant correlation was found between the reduction in the diameter and moisture retention of beef burgers $(\mathrm{R}=-0.89, \mathrm{p}<0.05)$.

\section{Texture profile of low-fat beef burger}

The highest percentage of inulin $(8 \%$ in formulation 1) resulted in a harder structure; however, the lowest hardness value was observed in the burger containing 5.3 $\%$ inulin and $2.7 \% \beta$-glucan (formulation 3 ) (Table 4). The regression coefficient (Table 3 ) indicated that only the linear and quadratic terms were significant $(p<0.01)$. The effect of inulin, $\beta$-glucan and breadcrumbs on the texture was proportional to the corresponding coefficient (inulin> breadcrumbs $>\beta$-glucan) at the same percentage. Thereby, inulin was the most effective factor in increasing the hardness of the product. The predicted regression coefficient for the hardness showed that the interaction between inulin and $\beta$-glucan, breadcrumbs and $\beta$-glucan, and breadcrumbs and inulin had antagonistic effect on the hardness of the burgers. The contour plot of hardness indicated that the highest hardness values were in the inulin vertex and the lowest values were in the crossing of inulin and $\beta$-glucan interaction (Fig. 2a).

The highest cohesiveness was measured in the formulations containing only breadcrumbs $(8 \%$ in formulation 6 ) and the lowest value was recorded in the formulation containing equal mass fractions of inulin and $\beta$-glucan (formulation 4). The linear regression terms were highly significant $(p<0.01)$. In the predicted model, strong antagonistic effects of the two-component interaction on cohe- siveness were observed $(\mathrm{p}<0.01)$ (Table 3$)$. The lowest cohesiveness values were observed in the crossing of $\beta$-glucan and inulin, whereas the highest values were found along the breadcrumb and/or inulin vertex (Fig. 2b).

The highest value of gumminess $(23.4 \mathrm{~N})$ was recorded in burgers containing only inulin (formulation 1). However, burgers containing $5.3 \%$ inulin, $2.7 \% \beta$-glucan and $5.3 \% \beta$-glucan (formulations 2,3 and 14, respectively) had lower gumminess values. As shown in Table 3, the linear terms and the two-component interactions had highly significant effects on gumminess value $(\mathrm{p}<0.01)$. The absolute value of the coefficient of inulin was greater than of breadcrumbs and $\beta$-glucan, meaning that inulin had greater effect on gumminess value compared to two other ingredients. The contour plot confirmed that the highest gumminess value was associated with inulin vertex (Fig. 2c).

The observed differences in textural profiles of 14 formulations can be attributed to the different impacts of the used hydrocolloids (inulin and/or $\beta$-glucan) or breadcrumbs as well as their interactions, mainly the possible interplay of added hydrocolloids with the starch content of breadcrumbs. Hydrocolloids can modify the gelatinisation of starch in the following ways: (i) decreasing the available water for swelling of starch and increasing the gelatinisation temperature, or (ii) molecular interaction with the starch granules to produce a more stable structure, which can result in an increase of the gelatinisation temperature (22). Suppressing the swelling of starch granules resulted in reduced amylose leaching, and consequently, disturbed network formation (22). Swelling of the starch granules surrounded by protein gel matrices resulted in the formation of strong heat-induced structure, and thereby, in the beef burger with a firm and more compact structure (23). Addition of $\beta$-glucan to the formulation containing breadcrumbs decreased the hardness, cohesiveness and gumminess of the burgers. This

Table 4. Experimental results for texture and colour parameters of each burger formulation

\begin{tabular}{|c|c|c|c|c|c|c|}
\hline Formulation & Hardness/N & Cohesiveness & Gumminess/N & $L^{*}$ & $a^{*}$ & $b^{*}$ \\
\hline 1 & $(36.6 \pm 0.3)^{c}$ & $(0.64 \pm 0.01)^{\mathrm{e}}$ & $(23.4 \pm 0.6)^{\mathrm{e}}$ & $(20.3 \pm 0.6)^{\mathrm{d}}$ & $(3.8 \pm 0.8)^{\mathrm{a}}$ & $(11.8 \pm 1.7)^{\mathrm{abc}}$ \\
\hline 2 & $(4.9 \pm 0.5)^{\mathrm{a}}$ & $(0.50 \pm 0.02)^{\mathrm{a}}$ & $(2.4 \pm 0.3)^{\mathrm{a}}$ & $(17.0 \pm 2.1)^{\mathrm{a}}$ & $(5.7 \pm 0.9)^{\mathrm{b}}$ & $(11.3 \pm 0.6)^{\mathrm{ab}}$ \\
\hline 3 & $(4.7 \pm 0.4)^{\mathrm{a}}$ & $(0.50 \pm 0.01)^{\mathrm{a}}$ & $(2.6 \pm 0.3)^{\mathrm{a}}$ & $(19.2 \pm 0.3)^{\mathrm{cd}}$ & $(3.4 \pm 0.5)^{\mathrm{a}}$ & $(11.9 \pm 0.8)^{\mathrm{abc}}$ \\
\hline 4 & $(5.5 \pm 0.3)^{\mathrm{a}}$ & $(0.49 \pm 0.01)^{\mathrm{a}}$ & $(2.9 \pm 0.2)^{\mathrm{a}}$ & $(17.8 \pm 0.1)^{\mathrm{abc}}$ & $(3.5 \pm 0.3)^{\mathrm{ab}}$ & $(10.5 \pm 0.2)^{\mathrm{ab}}$ \\
\hline 5 & $(8.4 \pm 0.6)^{a}$ & $(0.56 \pm 0.01)^{\mathrm{cd}}$ & $(5.4 \pm 0.3)^{\mathrm{ab}}$ & $(18.0 \pm 0.5)^{\mathrm{abc}}$ & $(4.3 \pm 0.4)^{\mathrm{ab}}$ & $(12.5 \pm 0.5)^{\text {abcde }}$ \\
\hline 6 & $(20.0 \pm 4.2)^{\mathrm{b}}$ & $(0.68 \pm 0.01)^{\mathrm{e}}$ & $(13.7 \pm 2.6)^{\mathrm{d}}$ & $(19.5 \pm 1.2)^{\mathrm{cd}}$ & $(4.2 \pm 0.9)^{\mathrm{ab}}$ & $(13.7 \pm 1.5)^{\mathrm{bcd}}$ \\
\hline 7 & $(6.0 \pm 0.9)^{\mathrm{a}}$ & $(0.54 \pm 0.01)^{\mathrm{bc}}$ & $(4.1 \pm 0.5)^{\mathrm{ab}}$ & $(17.1 \pm 0.6)^{\mathrm{ab}}$ & $(6.0 \pm 0.8)^{\mathrm{b}}$ & $(14.7 \pm 0.1)^{\text {cde }}$ \\
\hline 8 & $(8.7 \pm 1.1)^{\mathrm{a}}$ & $(0.50 \pm 0.02)^{\mathrm{a}}$ & $(3.9 \pm 0.3)^{\mathrm{ab}}$ & $(17.8 \pm 0.3)^{\mathrm{abc}}$ & $(4.9 \pm 0.6)^{\mathrm{ab}}$ & $(11.9 \pm 1.2)^{\mathrm{abc}}$ \\
\hline 9 & $(19.8 \pm 1.6)^{\mathrm{b}}$ & $(0.58 \pm 0.01)^{\mathrm{d}}$ & $(11.5 \pm 0.7)^{\mathrm{cd}}$ & $(19.2 \pm 0.6)^{\mathrm{bcd}}$ & $(3.9 \pm 0.4)^{\mathrm{ab}}$ & $(9.5 \pm 2.0)^{\mathrm{a}}$ \\
\hline 10 & $(5.8 \pm 0.9)^{\mathrm{a}}$ & $(0.52 \pm 0.01)^{\mathrm{ab}}$ & $(3.1 \pm 0.5)^{\mathrm{ab}}$ & $(17.6 \pm 0.9)^{\mathrm{abc}}$ & $(5.2 \pm 0.9)^{\mathrm{ab}}$ & $(15.5 \pm 2.2)^{\mathrm{de}}$ \\
\hline 11 & $(5.9 \pm 0.1)^{\mathrm{a}}$ & $(0.57 \pm 0.01)^{\mathrm{cd}}$ & $(3.5 \pm 0.3)^{\mathrm{ab}}$ & $(17.3 \pm 1.5)^{\mathrm{ab}}$ & $(5.9 \pm 0.4)^{\mathrm{b}}$ & $(15.7 \pm 0.2)^{\text {def }}$ \\
\hline 12 & $(8.5 \pm 0.9)^{\mathrm{a}}$ & $(0.50 \pm 0.01)^{\mathrm{a}}$ & $(4.2 \pm 0.5)^{\mathrm{ab}}$ & $(17.9 \pm 0.3)^{\mathrm{a}}$ & $(5.0 \pm 0.4)^{\mathrm{ab}}$ & $(11.5 \pm 1.1)^{\mathrm{abc}}$ \\
\hline 13 & $(19.7 \pm 1.2)^{\mathrm{b}}$ & $(0.59 \pm 0.01)^{\mathrm{d}}$ & $(11.1 \pm 0.8)^{\mathrm{c}}$ & $(19.0 \pm 0.6)^{\mathrm{abcd}}$ & $(3.7 \pm 0.5)^{\mathrm{ab}}$ & $(9.7 \pm 1.8)^{\mathrm{a}}$ \\
\hline 14 & $(5.2 \pm 0.3)^{\mathrm{a}}$ & $(0.52 \pm 0.02)^{\mathrm{ab}}$ & $(2.7 \pm 0.2)^{\mathrm{a}}$ & $(17.8 \pm 0.7)^{\mathrm{abc}}$ & $\mathrm{v}(4.8 \pm 0.9)^{\mathrm{ab}}$ & $(12.6 \pm 0.5)^{\mathrm{abcd}}$ \\
\hline
\end{tabular}

Values are mean \pm standard deviation of three repetitions. Mean values in the same column with the same letter are not significantly different. $L^{*}=$ lightness, $a^{*}=$ redness, $b^{*}=$ yellowness

For the composition of formulations see Table 1 

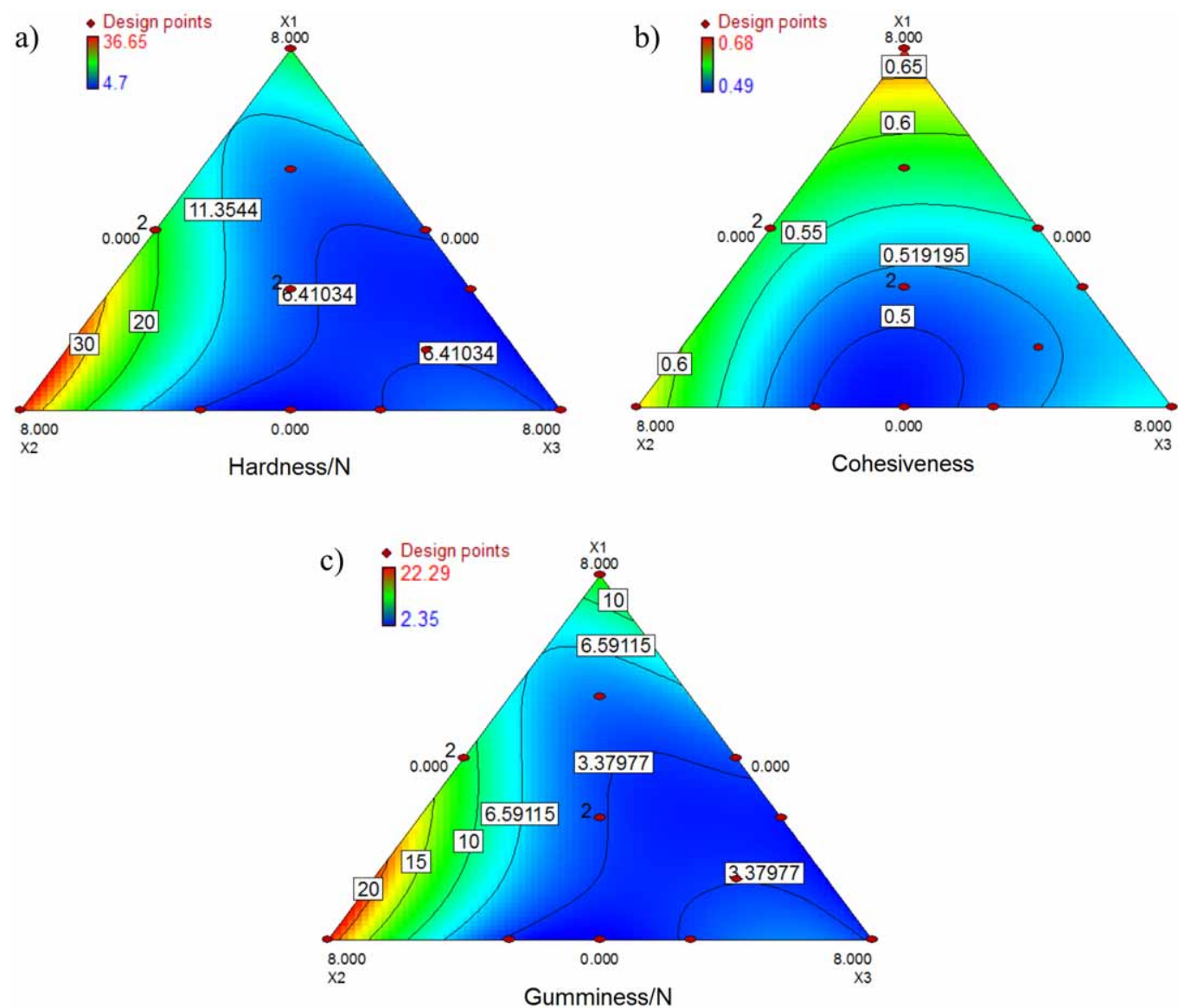

Fig. 2. Contour plots for the effect of the addition of breadcrumbs $\left(X_{1}\right)$, inulin $\left(X_{2}\right)$ and $\beta$-glucan $\left(X_{3}\right)$ on texture parameters of the low-fat beef burgers containing canola and olive oil blend

was probably due to reduced amount of available water for swelling of the starch granules, which led to an increase in gelatinisation temperature.

The addition of powdered inulin to the formulation caused higher moisture release during cooking, which changed the texture of burgers, i.e. increased hardness. Similar result was obtained by García et al. (24), who indicated that incorporating powdered inulin in the low-fat and full-fat mortadella increased textural hardness. Menegas et al. (12) showed that the addition of powdered inulin in reduced-fat sausages also resulted in increased hardness.

According to the regression coefficients in Table 3, it can be observed that the mixture of inulin and $\beta$-glucan in burger formulation decreases the hardness, cohesiveness and gumminess of the products. However, when the mass fraction of inulin in the mixture was higher than of $\beta$-glucan, these parameters increased. Possible explanation is related to the reduction in moisture retention of the burgers that amplifies the compactness of the protein network (more firm and cohesive structure). In this study, the hardness of burger texture was significantly correlated with the loss of moisture during cooking $(\mathrm{R}=0.87, \mathrm{p}<0.01)$.

\section{Differences in colour parameters of low-fat beef burgers}

The highest $L^{*}$ value (lightness) was recorded in the low-fat beef burger containing only inulin $(8 \%$ in formu- lation 1), but the lowest lightness was observed in the formulation with $8 \% \beta$-glucan (formulation 7 ) (Table 4). The predicted regression analyses for the lightness showed that the linear terms were highly significant $(p<0.01)$ and the two-component interactions had a significantly negative effect $(\mathrm{p}<0.05)($ Table 3$)$. The lowest $L^{*}$ value was in the $\beta$-glucan vertex, whereas the highest one appeared to be in the inulin vertex (Fig. 3a). Moreover, the highest $a^{*}$ value (redness) was obtained when the highest mass fraction of $\beta$-glucan was added to the burger mixture (formulation 7); the lowest $a^{*}$ value was determined in the sample with the highest mass fraction of inulin (formulation 1 ). For redness value (Table 3 ), the regression coefficients for the linear terms were highly significant $(p<0.01)$. In the contour plot, the lowest value was observed in the inulin vertex, whereas the highest value was recorded in the $\beta$-glucan vertex (Fig. $3 \mathrm{~b}$ ). The yellowness value $\left(b^{*}\right)$ was slightly higher in the burgers containing equal mass fractions of $\beta$-glucan and breadcrumbs or containing only $8 \%$ $\beta$-glucan (formulations 11 and 7 , respectively) and lower in the burgers containing equal mass fractions of inulin and breadcrumbs (formulation 9) (Table 4). According to the regression coefficient given in Table 3, the linear terms and the $\beta$-glucan and breadcrumbs interaction had highly significant effect on yellowness values. The highest yellowness value in the predicted contour plot was obtained in the $\beta$-glucan vertex or when $\beta$-glucan was added to the formulation containing high mass fraction of breadcrumbs (Fig. 3c). 

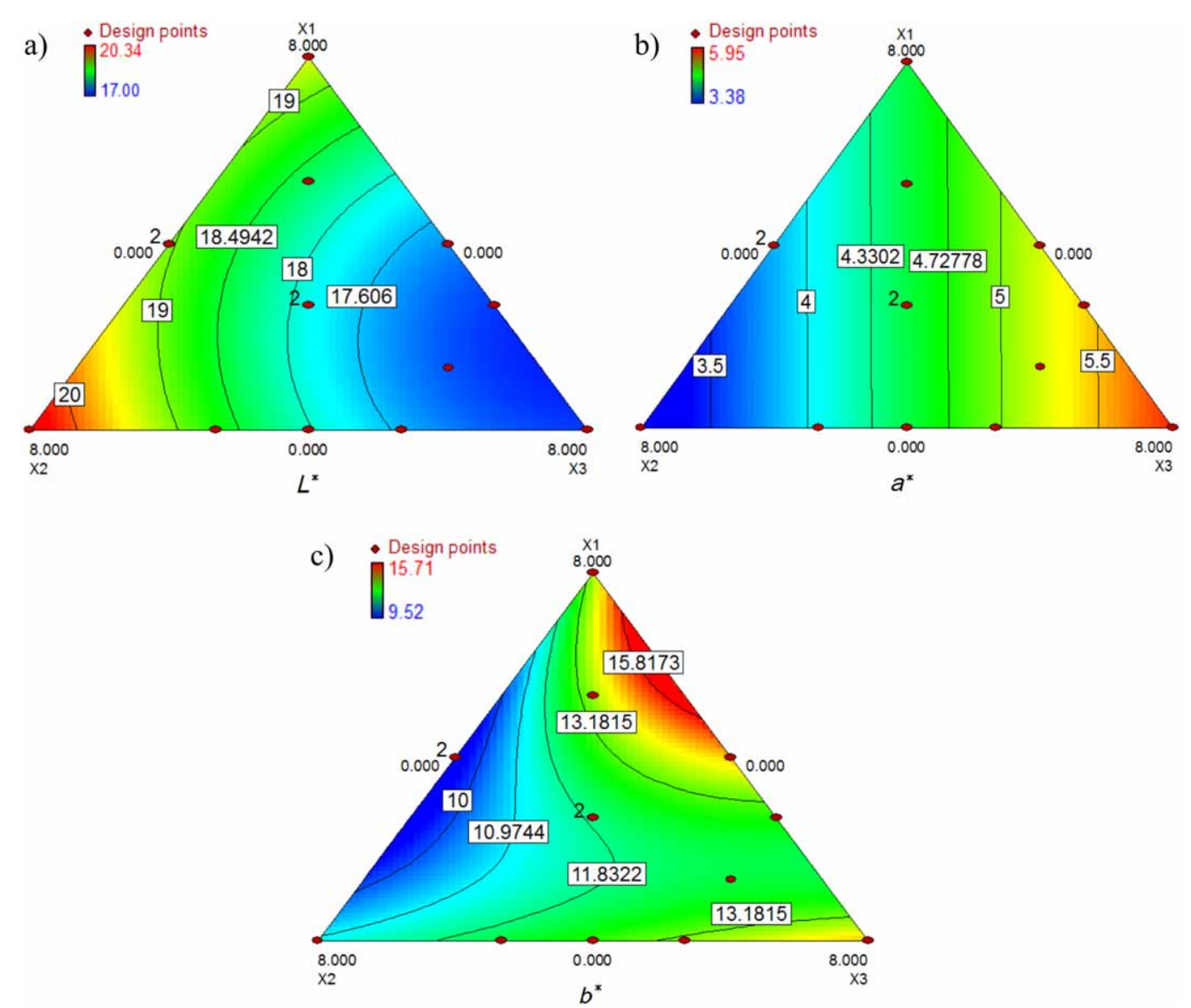

Fig. 3. Contour plots for the effect of the addition of breadcrumbs $\left(X_{1}\right)$, inulin $\left(X_{2}\right)$ and $\beta$-glucan $\left(X_{3}\right)$ on colour parameters ( $L^{*}=$ lightness, $a^{*}=$ redness, $b^{*}=$ yellowness) of the low-fat beef burgers containing canola and olive oil blend

Among the 14 formulations, the mass fraction and the type of fat remained constant, so the observed differences in colour values were probably due to the effect of added hydrocolloids and breadcrumbs individually and their interaction as well. In this study, higher moisture retention and higher cooking yield resulted in lower lightness and higher redness of beef burgers, which is in agreement with the findings of García-García and Totosaus (25). Higher moisture release and higher cooking loss were significantly correlated with lightness $(R=0.916$, $\mathrm{p}<0.01$ and $\mathrm{R}=0.928, \mathrm{p}<0.01$, respectively). Since the addition of inulin to the burgers led to higher moisture release and lower cooking yield, the burgers containing inulin seemed to be lighter. However, the addition of $\beta$-glucan increased cooking yield and moisture retention and thus decreased the lightness. This finding was in contrast with the results obtained when $\beta$-glucan was added to the sausages, suggesting that $\beta$-glucan increased the lightness (26). Observed differences in yellowness values of the burgers were probably due to the differences in the natural colour of the added ingredients.

\section{Sensory scores of low-fat beef burgers}

Formulation 1 (containing $8 \%$ inulin) received the highest overall acceptability score, while burgers with the highest mass fraction of $\beta$-glucan (formulation 7) received the lowest scores (Table 5). The regression coefficient val-
Table 5. Scores of overall acceptability and mouldability of low-fat beef burgers

\begin{tabular}{ccc}
\hline Formulation & Overall acceptability & Mouldability \\
\hline 1 & $(7.1 \pm 0.7)^{\mathrm{c}}$ & $(4.7 \pm 0.5)^{\mathrm{d}}$ \\
2 & $(5.4 \pm 1.9)^{\mathrm{abc}}$ & $(3.6 \pm 0.8)^{\mathrm{c}}$ \\
3 & $(6.1 \pm 0.8)^{\mathrm{bc}}$ & $(3.8 \pm 0.8)^{\mathrm{c}}$ \\
4 & $(4.9 \pm 0.9)^{\mathrm{a}}$ & $(2.4 \pm 1.2)^{\mathrm{b}}$ \\
5 & $(6.6 \pm 0.7)^{\mathrm{c}}$ & $(4.2 \pm 0.9)^{\mathrm{d}}$ \\
6 & $(6.6 \pm 0.8)^{\mathrm{c}}$ & $(4.9 \pm 0.3)^{\mathrm{d}}$ \\
7 & $(4.7 \pm 0.7)^{\mathrm{a}}$ & $(1.2 \pm 0.4)^{\mathrm{a}}$ \\
8 & $(5.5 \pm 1.1)^{\mathrm{ab}}$ & $(3.0 \pm 0.8)^{\mathrm{bc}}$ \\
9 & $(6.6 \pm 1.1)^{\mathrm{c}}$ & $(4.6 \pm 0.5)^{\mathrm{d}}$ \\
10 & $(5.3 \pm 1.05)^{\mathrm{a}}$ & $(1.4 \pm 0.7)^{\mathrm{a}}$ \\
11 & $(5.6 \pm 0.8)^{\mathrm{b}}$ & $(1.4 \pm 0.8)^{\mathrm{a}}$ \\
12 & $(5.5 \pm 1.02)^{\mathrm{ab}}$ & $(2.9 \pm 1.1)^{\mathrm{b}}$ \\
13 & $(6.5 \pm 1.1)^{\mathrm{c}}$ & $(4.5 \pm 0.5)^{\mathrm{d}}$ \\
14 & $(4.9 \pm 0.9)^{\mathrm{a}}$ & $(1.4 \pm 0.9)^{\mathrm{a}}$ \\
\hline
\end{tabular}

Values are mean \pm standard deviation. Mean values in the same column with the same letter are not significantly different For the composition of the formulations see Table 1

ues of overall acceptability indicated that this response was affected significantly by the linear terms $(p<0.01)$ (Ta- 
ble 3). The lowest scores of overall acceptability in the contour plot were observed in the $\beta$-glucan vertex and a linear increase of overall acceptability scores was observed towards the edge of inulin and breadcrumbs interaction (Fig. 4a). The highest (4.9) and the lowest (1.2) scores for mouldability were given to formulations 6 and 7 , respectively, by experienced panellists. The linear regression model was highly significant for this response $(p<0.01)$, and the highest regression coefficient value was attributed to inulin, followed by breadcrumbs (Table 3). In the contour plot, the lowest scores for mouldability were observed in the $\beta$-glucan vertex (Fig. $4 \mathrm{~b}$ ). Consequently, the addition of high mass fractions of inulin improved the mouldability and overall acceptance of the burgers compared with the addition of $\beta$-glucan.
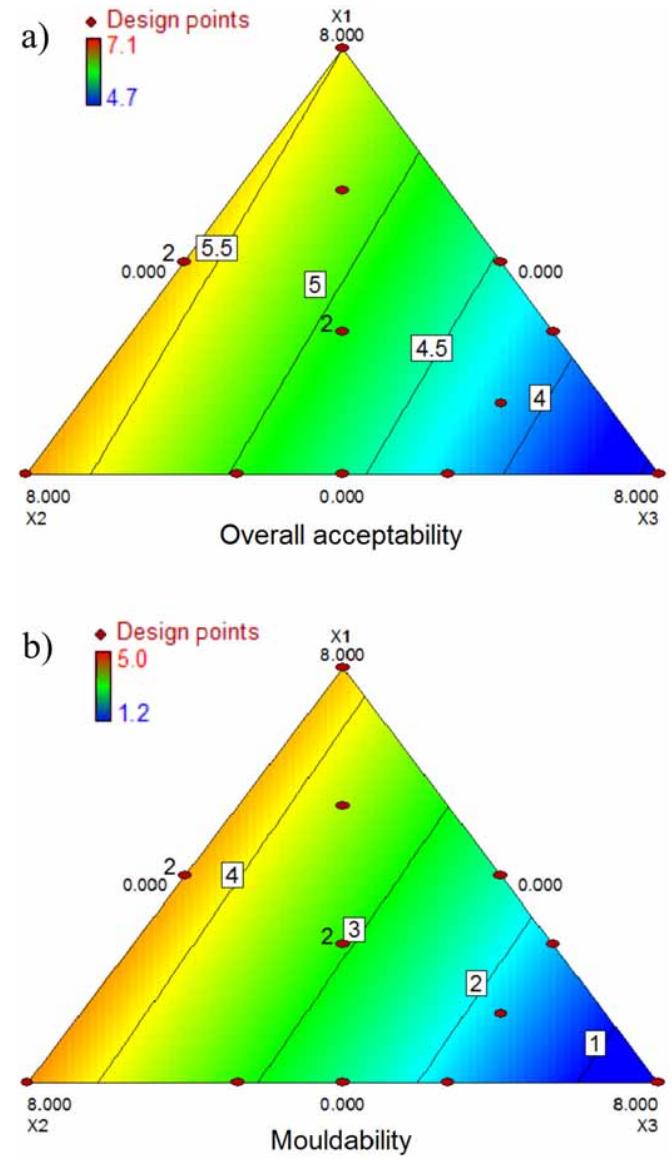

Fig. 4. Contour plots for the effect of the addition of breadcrumbs $\left(X_{1}\right)$, inulin $\left(X_{2}\right)$ and $\beta$-glucan $\left(X_{3}\right)$ on overall acceptability and mouldability of the low-fat beef burgers containing canola and olive oil blend

\section{Mixture proportion optimisation}

The aim of the optimisation was to predict the optimal variables for some of the important responses which had a great influence on quality properties of burgers. The observed and predicted values of the responses along with the mixture proportions are shown in Table 6.

Our aim was to maximise cooking yield, mouldability and overall acceptability, and minimise the reduction in diameter of the burgers, while maintaining the mass fractions of inulin, breadcrumbs and $\beta$-glucan within range. By using the given criteria, two mixtures were suggested (mixture 1: $2.7 \%$ breadcrumbs, $3.1 \%$ inulin and $2.2 \% \beta$-glucan; and mixture 2: $5.8 \%$ inulin and $2.2 \%$ $\beta$-glucan) (Table 6). Mixture 1 was selected as the best because it received higher $(71.6 \%)$ desirability score (Table $6)$. The optimum formulation could provide valuable nutritional and technological properties in comparison with traditional beef burgers. Furthermore, introducing the changes in the formulation did not have negative effects on sensory properties of the product.

\section{Conclusion}

D-optimal mixture design approach was used to optimise the formulation of beef burgers. According to the experimental results and the map of contour plots, addition of inulin to the formulation had a predominant effect on cooking characteristics, textural and colour parameters of cooked burgers. Addition of inulin to the formulation of low-fat beef burgers decreased cooking yield and moisture retention; furthermore, it increased the lightness, mouldability, overall acceptance of the burgers and the textural parameters, while adding $\beta$-glucan had inverse effects. In this study, the interaction between inulin and $\beta$-glucan improved the cooking characteristics of the product without having a significantly negative effect on the colour and sensory attributes of the burgers. Therefore, according to the obtained results, the mixture of inulin and $\beta$-glucan can be used in the formulation of low-fat beef burgers. This mixture not only offsets some negative effects attributed to the fat level reduction and total replacement of beef fat by vegetable oils, but also improves some cooking properties and texture of the products along with enhancing nutritional characteristics.

\section{Acknowledgement}

This research was funded by National Nutrition and Food Technology Research Institute (NNFTRI) of Iran (project code: P.25.47.3564). Authors gratefully acknowl-

Table 6. Optimum levels of independent variables along with predicted and observed values of the responses

\begin{tabular}{|c|c|c|c|c|c|c|c|c|c|c|c|c|}
\hline \multirow{2}{*}{ Mixture } & \multirow{2}{*}{$X_{1}$} & \multirow{2}{*}{$X_{2}$} & \multirow{2}{*}{$X_{3}$} & \multicolumn{2}{|c|}{$\eta_{\text {cooking }} / \%$} & \multicolumn{2}{|c|}{$d_{\text {reduction }} / \%$} & \multicolumn{2}{|c|}{ Overall acceptance } & \multicolumn{2}{|c|}{ Mouldability } & \multirow{2}{*}{ Desirability/\% } \\
\hline & & & & OV & PV & OV & PV & OV & PV & OV & PV & \\
\hline 1 & 2.7 & 3.1 & 2.2 & 73.7 (1.2) & 72.9 & $11.8(0.6)$ & 13.1 & $5.7(1.2)$ & 6 & $3(0.5)$ & 3.3 & 71.6 \\
\hline 2 & 0 & 5.8 & 2.2 & $64.5(0.8)$ & 66.2 & $19.1(0.5)$ & 17.2 & $6.2(0.9)$ & 6.8 & $4(0.6)$ & 3.4 & 68 \\
\hline
\end{tabular}

$X_{1}=$ breadcrumbs, $X_{2}=$ inulin, $X_{3}=\beta$-glucan

$\mathrm{OV}=$ observed value, $\mathrm{PV}=$ predicted value 
edge Gooshtiran Co., Tehran, Iran, for their help in manufacturing burgers.

\section{References}

1. McAfee AJ, McSorley EM, Cuskelly GJ, Moss BW, Wallace JMW, Bonham MP, Fearon AM. Red meat consumption: an overview of the risks and benefits. Meat Sci. 2010;84:1-13. http://dx.doi.org/10.1016/j.meatsci.2009.08.029

2. Williamson CS, Foster RK, Stanner SA, Buttriss JL. Red meat in the diet. Nutr Bull. 2005;30:323-55. http://dx.doi.org/10.1111/j.1467-3010.2005.00525.x

3. Beriain MJ, Gómez I, Petri E, Insausti K, Sarriés MV. The effects of olive oil emulsified alginate on the physico-chemical, sensory, microbial, and fatty acid profiles of low-salt, inulin enriched sausages. Meat Sci. 2011;88:189-97. http://dx.doi.org/10.1016/j.meatsci.2010.12.024

4. Delgado-Pando G, Cofrades S, Ruiz-Capillas C, Solas MT, Jiménez-Colmenero F. Healthier lipid combination oil-in-water emulsions prepared with various protein systems: an approach for development of functional meat products. Eur J Lipid Sci Tech. 2010;112:791-801. http://dx.doi.org/10.1002/ejlt.200900234

5. Choi YS, Choi JH, Han DJ, Kim HY, Lee MA, Kim HW, et al. Characteristics of low-fat meat emulsion systems with pork fat replaced by vegetable oils and rice bran fiber. Meat Sci. 2009;82:266-71. http://dx.doi.org/10.1016/j.meatsci.2009.01.019

6. Park JC, Jeong JY. Lee ES, Choi JH, Choi YS, Yu LH, et al. Effects of replaced plant oils on the quality properties in lowfat hamburger patties. Korean J Food Sci Technol. 2005;37: 412-7 (in Korean).

7. Troy DJ, Desmond EM, Buckley DJ. Eating quality of low-fat beef burgers containing fat-replacing functional blends. J Sci Food Agric. 1999;79:507-16. http://dx.doi.org/10.1002/(SICI)1097-0010(19990315)79:4<507: :AID-JSFA209>3.0.CO;2-6

8. Morin LA, Temelli F, McMullen L. physical and sensory characteristics of reduced-fat breakfast sausages formulated with barley $\beta$-Glucan. J Food Sci. 2002;67:2391-6. http://dx.doi.org/10.1111/j.1365-2621.2002.tb09559.x

9. Tudorica CM, Jones TER, Kuri V, Brennan CS. The effects of refined barley $\beta$-glucan on the physico-structural properties of low-fat dairy products: curd yield, microstructure, texture and rheology. J Sci Food Agric. 2004;84:1159-69. http://dx.doi.org/10.1002/jsfa.1789

10. Piñero MP, Parra K, Huerta-Leidenz N, Arenas de Moreno L, Ferrer M, Araujo S, Barboza Y. Effect of oat's soluble fibre (beta-glucan) as a fat replacer on physical, chemical, microbiological and sensory properties of low-fat beef patties. Meat Sci. 2008;80:675-80.

http://dx.doi.org/10.1016/j.meatsci.2008.03.006

11. Volpini-Rapina LF, Sokei FR, Conti-Silva AC. Sensory profile and preference mapping of orange cakes with addition of prebiotics inulin and oligofructose. LWT - Food Sci Technol. 2012;48:37-42.

http://dx.doi.org/10.1016/j.lwt.2012.03.008

12. Menegas LZ, Pimentel TC, Garcia S, Prudencio SH. Dry-fermented chicken sausage produced with inulin and corn oil: physicochemical, microbiological, and textural characteristics and acceptability during storage. Meat Sci. 2013;93:501-6. http://dx.doi.org/10.1016/j.meatsci.2012.11.003

13. Selgas MD, Cáceres E, García ML. Long-chain soluble dietary fibre as functional ingredient in cooked meat sausages. Food Sci Technol Int. 2005;11:41-7. http://dx.doi.org/10.1177/1082013205051273

14. Jang MS, Park JE, Park HY. Formulation optimization of salad dressing added with Chinese quince (Chaenomelis sinensis) juice by mixture design. Food Sci Biotechnol. 2011;20: 409-17. http://dx.doi.org/10.1007/s10068-011-0058-x

15. Bloukas JG, Paneras ED, Fournitzis GC. Effect of replacing pork backfat with olive oil on processing and quality characteristics of fermented sausages. Meat Sci. 1997;45:133-44. http://dx.doi.org/10.1016/S0309-1740(96)00113-1

16. Research guidelines for cookery, sensory evaluation and instrumental tenderness measurements of meat. Chicago, IL, USA: American Meat Science Association (AMSA); 2015.

17. Mann HB, Whitney DR. On a test of whether one of two random variables is stochastically larger than the other. Ann Math Statist. 1947;18:50-60.

18. Dexter DR, Sofos JN, Schmidt GR. Quality characteristics of turkey Bologna formulated with carrageenan, starch, milk and soy protein. J Muscle Foods. 1993;4:207-23. http://dx.doi.org/10.1111/j.1745-4573.1993.tb00503.x

19. Zeidler G, Pasin G, Luh BS, Thompson JF, Rice RD. Reducing cooking time, yield losses and energy utilization of Salisbury steaks as affected by various meat extenders and meat composition. Foodservice Res Int. 1988;5:215-36. http://dx.doi.org/10.1111/j.1745-4506.1988.tb00135.x

20. Kim Y, Faqih MN, Wang SS. Factors affecting gel formation of inulin. Carbohydr Polym. 2001;46:135-45. http://dx.doi.org/10.1016/S0144-8617(00)00296-4

21. Álvarez D, Barbut S. Effect of inulin, $\beta$-glucan and their mixtures on emulsion stability, color and textural parameters of cooked meat batters. Meat Sci. 2013;94:320-7. http://dx.doi.org/10.1016/j.meatsci.2013.02.011

22. BeMiller JN. Pasting, paste, and gel properties of starch-hydrocolloid combinations. Carbohydr Polym. 2011;86:386-423. http://dx.doi.org/10.1016/j.carbpol.2011.05.064

23. Khalil AH. Quality characteristics of low-fat beef patties formulated with modified corn starch and water. Food Chem. 2000;68:61-8. http://dx.doi.org/10.1016/S0308-8146(99)00156-9

24. García ML, Cáceres E, Selgas MD. Effect of inulin on the textural and sensory properties of mortadella, a Spanish cooked meat product. Int J Food Sci Tech. 2006;41:1207-15. http://dx.doi.org/10.1111/j.1365-2621.2006.01186.x

25. García-García E, Totosaus A. Low-fat sodium-reduced sausages: effect of the interaction between locust bean gum, potato starch and $\kappa$-carrageenan by a mixture design approach. Meat Sci. 2008;78:406-13. http://dx.doi.org/10.1016/j.meatsci.2007.07.003

26. Amini Sarteshnizi R, Hosseini H, Bondarianzadeh D, Colmenero FJ, Khaksar R. Optimization of prebiotic sausage formulation: effect of using $\beta$-glucan and resistant starch by Doptimal mixture design approach. LWT - Food Sci Technol. 2015;62:704-10. http://dx.doi.org/10.1016/j.lwt.2014.05.014 